\title{
MENGELOLA PENDIDIKAN ISLAM RAUDLATUL ATHFAL
}

\author{
Taqiyuddin Masyhuri \\ Ketua Jurusan MPIIAIN Syekh Nurjati Cirebon \\ Email: ataqiyudin@gmail.com
}

\begin{abstract}
Abstrak
Kesadaran masyarakat terhadap masa depan pendidikan anaknya sejak usia dini telah merata, ironisnya lembaga pendidikan anak pertama di Indonesia perkembangannya sangat lambat dibandingkan pendidikan anak yang sederajat. Ditengarai karena pengelola pendidikan $R A$ belum menerapkan system manajemen pendidikan Islam; belum menyesuaikan dengan PP No. 19 tahun 2005 tentang standar nasional pendididikan (SNP), dan masyarakat yang memasukan anaknya kependidikan $R A$ bukan karena pendidikan $R A$ sebagai sistem pendidikan formal melainkan sebagai pendidikan Islam non formal padaumumnya. Hasil pengamatan dan komunikasi dengan para pengelola pendidikan RA diperoleh gambaran. Pertama, secara keseluruhan Kepala RA bersama Yayasan, sejak awal tahun pelajaran selalu merencanakan program pendidikan untuk satu tahun termasuk penyusunan satuan kegiatan mingguan (SKM) dan satuan kegiatan harian (SKH) dilaksanakan dalam bentuk pembelajaran. Kedua, dalam melaksanakan program pendidikannya, semua pengelola pendidikan $R A$ telah terorganisasi dan terlaksananya fungsi-fungsi manajemen pendidikan sesuai perannya masing-masing. Ketiga, semua Kepala $R A$ telah melakukan peran, fungsi dan tanggungjawabnya sebagai manajer yaitu pengarah, pengawas, dan penialaian kinerja guru dan stafnya.
\end{abstract}

Kata kunci : Manajemen Pendidikan Islam, RaudlatulAthfal

\section{Pendahuluan}

Pendidikan dapat dijadikan indikator kehidupan suatu bangsa; maju mundur-nya suatu bangsa sangat tergantung kepada kualitas pendidikannya. Atas dasar inilah berbagai bentuk dan jenis pendidikan Islam berdiri di berbagai daerah, sebagai upaya memediasi dan menyebar luaskan ajaran Islam kepada masyarakat. Melalui lembaga-lembaga pendidikan Islam itu, masyarakat Indonesia memahami, menghayati dan mengamalkan ajaran Islam sesuai al-Qur'an dan al-Sunnah.

Lembaga pendidikan Islam, di UU RI No. 20 tahun 2003 tentang SISDIK-
NAS termasuk kategori Pendidikan Keagamaan (psl. 30) yaitu “.... diselenggarakan oleh pemerintah dan/atau kelompok masyarakat (ayat 1), diselenggarakan pada jalur pen-didikan formal, nonformal dan informal (ayat 3), berbentuk ajaran diniyah, pondok pesantren (ayat 4). Lembaga pendidikan Islam yang diselenggarakan dalam bentuk pendidikan formal antara lain Madrasah Ibtidaiyah, sedangkan yang diselenggarakan dalam bentuk pendidikan nonformal antara lain Pesantren. Pasal 30 ini, tidak mencan-tumkan pendidikan Raudlatul Athfal (RA). Pendidikan RA diuraikan secara khusus pada pasal 28 tentang PAUD yaitu: diselenggarakan 
sebelum jenjang pendi-dikan dasar (ayat 1), diselenggarakan mela-lui jalur pendidikan formal, nonformal dan/atau informal (ayat 2); jalur pendidikan formal berbentuk TK dan RA (ayat 3). Ini artinya, pendidikan RA adalah pendidikan anak setara dengan TK, baik dalam penye-lenggaraannya maupun sistem pengelo-laannya. Yang membedakan dari keduanya adalah, TK di bawah pembinaan dan nau-ngan Kemendiknas sedangkan pendidikan RA di bawah pembinaan dan naungan Kementrian Agama RI

Pendidikan RA diselenggarakan secara formal, karena itu harus mengikuti sistem managerial yang berlaku yaitu memperoleh dukungan masyarakat, dipim-pin oleh seorang pemimpin yang ber-orientasi pada pengembangan pendidikan, memiliki sumber daya yang memadai dan memiliki kelengkapan sarana fasilitas yang optimal sebagai pendukung pembelajaran. Terkait sistem penyelenggaraan pendidikan, PP RI No 19 Th 2005 tentang Standar Nasional Pendidikan (SNP) telah mengatur bahwa semua jenis, bentuk dan jenjang pendidikan harus memiliki standar pendidikan meliputi: 1) Standar tingkat pencapaian perkembangan; 2) Standar pendidik dan tenaga kependidikan; 3) Standar isi, proses, dan penilaian; dan 4) Standar sarana dan prasarana, pengelolaan, dan pembia-yaan.

Pendidikan RA yang ada di Kabupaten Cirebon, hasil pengamatan penulis, masih banyak yang belum sesuai PP No. 19 tahun 2005 tentang SNP yaitu belum menyiapkan pendidik dan kependidikan yang sesuai kriteria; belum menyediakan infrastruktur yang sesui kebutuhan; dan kepala RA belum menjalankan dasar dan fungsi manajemen pendidikan secara maksimal. Terhadap ke-nyataan ini, ditengarai ada dua faktor penyebab. Faktor utama, pendidikan RA dikelola oleh Kepala RA yang tidak melak-sanakan fungsi dan dasar manajemen pendi-dikan Islam. Padahal, lembaga pendidikan akan berjalan dengan baik, efektif dan efisien, tujuan pembelajaran juga akan tercapai dengan optimal jika dikelola oleh manajer yang betul-betul memahami fungsi dan tujuan organisasi pendidikan Islam.

Faktor lain, pengelola pendidikan RA kurang berorientasi pada profesionalisme. Faktor ini erat berkaitan dengan minimnya keuangan pendidikan RA, karena latar belakang ekonomi orangtua murid RA mayoritas lemah merupakan ujung dari masalah ini. Padahal pengelola pendidikan RA hanya mengandalkan sumbangan dari orang tua murid. Bagaimana mungkin Kepala RA mengelola RA secara profe-sional, jika kondisi ekonomi keluarganya amburadul, bagaimana mungkin guru-guru pendidikan RA akan melaksanakan pembelajaran dengan baik, jika kebutuhan dasar keluarganya tidak terpenuhi?. Demikian juga karyawannya, mereka sulit bekerja serius ketika dibelit persoalan ekonomi (Mujamil Qomar, 2007: 21).

Berdasarkan kenyataan di atas, penulis berpandangan bahwa pendidikan RA di Kabupaten Cirebon belum menjalankan dasar dan fungsi-fungsi manajemen pendidi-kan dan belum sesuai PP No. 9 tahun 2005 tentang SistemNasionalPendidikan (SNP). Karena itu, peneliti ingin mengetahui lebih mendalam tentang bagaimana pelaksanaan fungsi dan dasar manajemen pendidikan yang dilaksanakan pendidikan RA di Kabupaten Cirebon, yang meliputi:

1. Apakah Kepala RA melaksanakan perencanaan pendidikan dalam mengelola pendidikan RA di Kabupaten Cirebon?

2. Apakah Kepala RA melaksanakan organizingterhadap sumber-sumber pendidikan RA di Kabupaten Cirebon,

3. Apakah Kepala RA melakukan actuating dalam mengelola tenaga pendi- 
dik dan tenaga kependidikan sesuai tugasnya di RA di Kabupaten Cirebon

4. Apakah Kepala RA melakukan pengawasan terhadap tenaga pendidik dan kependidikan yang ada di Raudlatul Athfal di Kabupaten Cirebon.

\section{Tujuan dan Manfaat Penelitian}

Penelitian ini bertujuan untuk mendeskripsikan tentang hal-hal sebagai berikut:

1. Planning atau perencanaan pendidikan yang dilakukan oleh pengelola pendi-dikan RA dalam mengelola pembela-jaran pendidikan RA di Kabupaten Cirebon

2. Organizing yang dilakukan Kepala RA terhadap sumber-sumber pendidikan RA di Kabupaten Cirebon,

3. Actuating yang dilakukan Kepala RA dalam mengelola sumber-sumber pen-didikan sesuai tugasnya di RA di Kabupaten Cirebon

4. Controlling yang dilakukan Kepala RA terhadap sumber-sumber pendidikan RA di Kabupaten Cirebon.

Paling tidak ada dua manfaat yang diharapkan dari hasil penelitian ini, yaitu:

1. Manfaat Teoretis. Secara teoretis, hasil penelitian ini diharapkan memberikan kontribusi terhadap pengelola lembaga pendidikan anak agar di masa-masa ke depan semakin efektif dan efisien melalui penerapan prinsip dan dasar-dasar manajemen pendidikan. Juga dapat memperkuat dalil bahwa mengelola PAUD harus berdasarkan peraturan dan perundangundangan yang berlaku.

2. Manfaat Praktis. Hasil studi ini diharapkan dapat memberikan kontribusi bagi masa depan pendidikan RA berkaitan dengan ajaran Islam yang berlandaskan pada al-quran, alsunnah, nalar dan naluri. Hasil pene- litian ini diharapkan dapat bermanfaat terutama bagi:

a. Pemerintah Pusat, dalam hal ini adalah Kemendiknas, agar hasil penelitian ini dapat dijadikan sebagai salah satu masukan dalam upaya memasyarakatkan program pendidikan anak usia 46 tahun,

b. Kementrian Agama (Kemenag) RI Kebupaten Cirebon, agar hasil penelitian ini dapat dijadi-kan masukan dalam memberikan ijin operasional kepada masya-rakat yang bermaksud mendiri-kan pendidikan RA,

c. Kepala lembaga pendidikan yang secara khusus melayani anak usia 4-6 tahun, agar dalam mengelola pendidikan harus benar-benar memahami sistem manajemen pendidikan dan menjalankan peraturan dan perundangundanganan yang berlaku,

d. Para pemerhati dan praktisi pendidikan anak, diharapkan hasil penelitian ini dapat dijadikan acuan dalam meyakinkan masyarakat bahwa, RA merupakan salah satu lembaga pendidikan anak yang sangat urgen dalam mendidik, membimbing dan mengasuh anak-anaknya.

\section{Fokus dan Kerangka Penelitian}

Penelitian ini difokuskan pada ditemukannya konsep, disain dan/atau model dalam mengelola lembaga pendidikan anak. Dalam pelaksanaannya, fokus penelitian ini adalah meneliti tentang proses pelaksanaan prinsip dan dasar-dasar manajemen pendidikan Islam meliputi Planning, Organizing, Actua-ting dan Controng di pendidikan RA di Kabupaten Cirebon; Dan meneliti tentang penerapan PP No. 19 tahun 2005 tentang Sistem Nasional Pendidikan (SNP) pada pendidikan RA di Kabupaten Cirebon. 
Dengan kalimat lain, fokus penelitian ini adalah mencari gambaran tentang pengelo-laan pendidikan RA di Kabupaten Cirebon dikelola secara profesional atau belum.

Lembaga pendidikan RA sebagai lembaga pendidikan formal, Kepala RA dalam pengelolaanya sudah seharusnya melaksanakan prinsip dan dasar manajemen pendidikan yaitu Planning, Organizing, Actuating dan Controng (POAC). Tanpa keempat prinsip dasar manajemen ini, organisasi pendidikan tidak akan berjalan dengan baik. Tujuan dasar manajemen pendidikan adalah, mengerjakan pekerjaan sesuai dengan "aturan main" yang telah ditentukan melalui job description sehingga akan diketahui dengan segera hasil pekerjaan sesuai dengan target waktu, jumlah dan kualitas.

Pengelola pendidikan RA yang mema-hami prinsip dasar manajemen pendidikan, akan menjalankan kewajibannya secara berkala dalam rangka memperbaiki kinerja sumber-sumber pendidikan yang ada. Prinsip manajemen lain yang tak kalah pentingnya adalah pengelolaan administrasi bidang keuangan. Ini dilakukan, selain untuk mewas-padai tindak penyelewengan juga untuk mengantisipasi hambatan dan kesulitan dalam masalah keuangan.

Selanjutnya mengatur sumbersumber organisasi pendidikan, baik manusia maupun non manusia, dalam jaringan tata kerja organisasi kelembagaan RA, kualifikasi tenaga yang menanganinya, baru kemudian merekrut tenaga yang memenuhi kualifikasi dengan memperhatikan prinsip-prinsip manajemen organisasi pendidikan.

\section{Kajian Teoritis}

Dalam tulisan ini, teori yang dijadikan rujukan meliputi al-Quran dan
al-Hadits, peraturan/perundang-undangan yang berlaku di Indonesia, pandangan para ahli pendi-dikan Islam dan pendidikan anak.

Ayat dan Hadits Manajemen Pendi-dikan Islam antara lain terdapat pada surat-surat dan Hadits di bawah ini.

1. Al-Quran surat Al-Nisa ayat 9, Allah berfirman yang artinya dan hendaknya takut kepada Allah orangorang yang seandainya meninggal di belakang mereka anak-anak yang lemah yang mereka khawatir terhadap (kesejah-teraan) mereka oleh karena itu hendaklah mereka bertaqwa pada Allah dan hendaklah mereka meng-ucapkan perkataan yang benar

2. Al-Quran surat al-A'raf ayat 172 , Allah berfirman yang artinya dan ingatlah ketika Tuhan mu mengeluarkan keturunan anak-anak Adam dari sulbi mereka dan Allah mengambil kesaksian terhadap jiwa mereka (seraya menjawab) bukankah Aku Tuhamu (mereka menjawab) betul, Engkau Tuhan kami, kami menjadi saksi (kami lakukan yang demikian itu) agar di hari kiamat kamu tidak mengatakan sesungguhnya kami (bani Adam) adalah orang-orang yang lengah terhadap ini (kesaksian Tuhan)

3. Al-Quran surat Al-Tahrim ayat 6, Allah berfirman yang artinya hai orang-orang yang beriman peliharalah dirimu dan keluargamu dari api neraka yang bahan bakarnya adalah manusia dan batu; penjaganya malai-kat-malaikan yang kasar, keras dan tidak mendurhakai Allah terhadap apa yang diperintahknNya kepada mereka dan selalu mengerakan apa yg diperintahkan

4. Pentingnya manajemen dalam pendidikan Islam adalah hadits Rasul yang diriwayatkan Imam Bukhari dan Muslim yang artinya, "setiap anak 
yang dilahirkan dalam keadaan suci maka kedua orang tuanyalah yang menjadikannya menjadi Yahudi, Nasran, atau Majusi".

5. Berkaitan dengan kewajibkan orang tua melayani pendidikan anaknya sejak anak usia 4-6 tahun. Rasulullah saw. dalam hadits yang diriwayatkan Anas bin Malik bersabda yang artinya, “.......... Jika ia telah berumur 6 tahun, maka didiklah ia tentang akhlaq, jika ia telah berumur sembilan tahun agar ia dipisahkan tempat tidurnya dan jika ia telah berumur 13 tahun dipukul ia agar mau menunai-kan kewajiban shalat............".

Keterkaitan dengan hal ini, masyarakat dan pemerintah Indonesia telah lama mengupayakan terbentuknya lembaga pen-didikan yang khusus melayani anak usia 4-6 tahun yaitu pendidikan RA, baik diseleng-garakan oleh swasta atau oleh pemerintah.

\section{Manajemen Pendidikan RA menurut Peraturan dan Perundang- undangan. Pendidikan RA adalah lembaga pendidikan Islam yang melayani pendidikan anak usia 4 - 6 tahun, dilaksanakan seperti lembaga pendidikan formal lainnya dan dipimpin oleh seorang kepala.}

Pengelolaan organisasi satuan PAUD jalur formal yang diselenggarakan oleh Pemerintah atau Pemerintah Daerah, memiliki dua organ yaitu Kepala Sekolah/ Madrasah yang menjalankan fungsi manajemen satuan pendidikan anak usia dini jalur formal dan komite Sekolah/Madrasah yang menjalankan fungsi pengarahan, pertimba-ngan, dan pengawasan akademik. Penge-lolaan satuan PAUD jalur formal, yang diselenggarakan oleh Pemerintah atau Pemda menggunakan tata kelola yang terdiri dari kepala Sekolah/Madrasah menjalankan manajemen berbasis Sekolah/ Madrasah untuk dan atas nama
Gubernur/ Bupati/ Walikota atau Menteri Agama sesuai ketentuan peraturan perundang-undangan; dan komite Sekolah/Madrasah memberikan bantuan pengarahan, pertimbangan, dan melakukan pengawasan akademik kepada dan terhadap kepala Sekolah/ Madrasah.

Dengan terbitnya Peraturan Pemerintah dan/atau perundang-undangan yang secara terus menerus disempurnakan tersebut, menunjukan bahwa pemerintah menaruh perhatian penuh terhadap penyelenggaraan pendidikan anak. Karena itu sewajarnyalah bagi setiap lembaga pendidi-kan atau pihak-pihak tertentu yang beren-cana untuk mendirikan pendidikan RA, seyogianya mengacu pada peraturan dan perundang-undangan yang telah diupayakan oleh pemerintah

1. Undang Undang RI Nomor 20 tahun 2003 tentang SISDIKNAS pasal 28 yang secara khusus membahas PAUD yaitu (Pendidikan RA) dise-lenggarakan sebelum jenjang pendidikan dasar (ayat 1), diselenggarakan melalui jalur pendidikan formal, nonformal dan/atau informal (ayat 2); jalur pendidikan formal berbentuk TK dan RA (ayat 3)

2. Peraturan Menteri Agama No 90 Tahun 2013 tentang Penyelenggaraan Pendidikan Madrasah bahwa, "Raudhatul Athfal adalah salah satu bentuk satuan pendidikan anak usia dini pada jalur pendidikan formal yang menyelengarakan program pen-didikan dengan kekhasan agama Islam bagi anak berusia 4 tahun sampai 6 (enam) tahun".

3. Peraturan Pemerintah RI No. 17 tahun 2010 tentang Pengelolaan dan Penyelenggaraan Pendidikan melalui Pasal 62 disebutkan, pendidikan anak melalui jalur pendidikan formal berbentuk TK, RA atau bentuk lain yang sederajat. Pasal berikutnya (pasal 63) menyebutkan, Murid atau anak yang belajar di 
TK/RA diatur melalui pasal berikutnya yang menyatakan bahwa, peserta didik TK, RA, atau bentuk lain yang sederajat, anak yang berusia 4 - 6 tahun.

4. Sebagai lembaga pendidikan formal, pendidikan RA harus memenuhi standar pendidikan sebagaimana tercantum dalam Peraturan Pemerintah RI no. 19 tahun 2005 tentang Standar Nasional Pendidikan (SNP). Melalui PP itu tercantum 8 standar yang harus dipenuhi oleh lembaga pendidikan formal yaitu: a.Standar isi; b.Standar proses; c.Standar kompetensi lulusan; d.Standar pendidik dan tenaga kependidikan; e.Standar sarana dan prasarana; f.Standar pengelolaan; g.Standar pembiayaan; dan h. Standar penilaian pendidikan.

5. Standar isi, standar proses, standar kompetensi lulusan, dan standar penilaian dibahas dalam kurikulum pendidikan RA. Bagian ini membahas standar pendidik dan tenaga kependidikan dan standar pengelolaan. Standar pendidik dan tenaga kependidikan yang terdiri dari kualifikasi akedemik dan kompetensi guru RA diatur pada Permendiknas No. 16 tahun 2007 tanggal 4 Mei 2007 tentang Standar Kualifikasi Akademik dan Kompetensi Guru. Struktur tenaga kependidikandi pendidikan RA minimal terdiri dari Kepada Sekolah, guru, dan tenaga administrasi. Guru-guru yang belum memiliki kualifikasi D-4 atau S1 diberikan status sebagai guru bantu.

6. Standar pengelolaan pendidikan RA juga diatur dalam Peraturan Pemerintah RI No. 66 tahun 2010 tentang Perubahan atas Peraturan Peme-rintah Nomor 17 tahun 2010 tentang Pengelolaan dan Penyelenggaraan Pendidikan. Pada pasal 1 ayat 5 dinyatakan bahwa pendidikan RA, adalah salah satu bentuk satuan pendidikan anak usia dini pada jalur pendidikan formal yang menyeleng-garakan program pendidikan dengan kekhasan agama Islam bagi anak berusia 4 - 6 tahun.

Manajemen Pendidikan menurut Para Ahli. Tokoh manajemen yang pendapatnya banyak dimanfaatkan para manajer pendidikan Islam adalah GR Terry. Terry (2014:9) mengemukakan, manajemen merupakan suatu kegiatan, pelaksanaanya disebut manajing dan orang yang melaku-kannya disebut manajer. Sebagai suatu kegiatan, manajemen menghentikan kecenderungan untuk melaksanakan segala sesuatu seorang diri, tugas operasionalnya dilaksanakan melalui upaya-upaya anggotanya. Tugas manajer adalah memanfaatkan usaha-usaha anggotanya secara efektif. Manajemen mancakup kegiatan untuk mencapai tujuan, dilakukan oleh sekelom-pok orang melalui tindakan-tindakan yang telah ditetapkan sebelumnya.

Malayu SP Hasibuan (2011:2) berpen-dapat manajemen adalah suatu proses yang khas yang terdiri dari tindakan perencanaan, pengorganisasian, pengarahan dan pengen-dalian yang dilakukan untuk menentukan serta mencapai sasaran-sasaran yang telah ditentukan melalui pemanfaatan sumber daya manusia dan sumber-sumber lainnya. Husaini Usman (2009:12) yang menuliskan, manajemen dapat diartikan sebagai proses perencanaan, pengorganisasian, pengarahan dan pengendalian sumber daya pendidikan untuk mencapai tujuan pendidikan secara efektif, efisien mandiri dan akuntabel. Beberapa pendapat ini mengarah kepada inti manajemen yaitu perencanaan (planning), pengorganisasian (organizing), pengarahan/ penggerakan (actuating) dan pengendalian/pengawasan (controlling).

Perkembangan berikutnya, sistem manajemen dilaksanakan di lembaga "pend-idikan umum" dan di lembaga 
pendidikan Islam. Manajemen pendidikan Islam, Mujamil Qomar (2007:16-17) menuliskan pembahasan manajemen pendidikan Islam selalu melibatkan wahyu dan budaya kaum muslimin, ditambah kaidah-kaidah mana-jemen "pendidikan umum", sehingga bangu-nan manajemen pendidikan Islam diletakan di atas empat sandaran yaitu: 1) Sandaran teologis, menimbulkan keyakinan adanya kebenaran pesan-pesan wahyu, karena berasal dari Allah; 2) Sandaran rasional, menimbulkan keyakinan kebenaran berdasarkan pertimbangan akal pikiran; 3) Sandaran empiris, menimbulkan keyakinan adanya kebenaran berdasarkan data-data riil dan akurat, 4) Sandaran teoritis, menim-bulkan keyakinan adanya kebenaran ber-dasarkan akal pikiran dan skaligus di-praktekan berkali-kali dalam pengelolaan pendidikan. Ini artinya, hakikat manajemen adalah al-tadbir. Kata ini merupakan deri-vasi dari kata dabbara yang berarti "me-gatur" banyak terdapat dalam Al-Qur'an (Ramayulis, 2008:260)

\section{Metode Penelitian}

Metode yang digunakan dalam penelitian ini adalah metode kualitatif dalam rangka mengkaji sesuatu yang sifatnya penghayatan dan pendalaman terhadap sesuatu yang dinilai penting untuk diteliti. Tujuannya untuk mengetahui apakah Kepala RA menjalankan fungsi-fungsi manajemen pendidikan?. Dalam pengumpulan data digunakan wawancara mendalam dan meng-amati suatu peristiwa yang terjadi dan dilaksanakan tanpa mencari tahu ada atau tidak adanya hubungan peristiwa itu dengan peristiwa lainya.

Pendekatan yang dilakukan peneliti yaitu pengamatan dan wawancara mendalam. Wawancara mendalamdilakukan secara langsung dengan informan kemudian peneliti mengembangkannya, baik ketera-ngan yang bersifat konseptual maupun kategorisasi. Wawancara mendalam dilaku-kan terkait kegiatan Kepala RA, para ustadz, para pegawai,
Sapras yang dimiliki RA. Wawancara juga dilakukan dengan orangtua yang anaknya belajar di pendidikan RA, Pengurus Ikatan Guru RA (IGRA) dan tokoh masyarakat Kabupaten Cirebon. Pertanyaan yang diajukan, dirumuskan berdasarkan konteks permasalahan, sedang-kan pengamatan dilakukan sejak diperoleh ijin penelitian, hingga saat-saat wawancara mendalam berlangsung bahkan setelah wawancara telah selesai. Saat itu peneliti juga terlibat secara langsung dalam kegiatan responden sehari-hari.

\section{Pembahasan}

Telah dikemukakan, bahwa management adalah proses Planning, Organizing, Actuating dan Controling (POAC) yang dilakukan para anggota organisasi dan pengguna sumber daya organisasi lainnya agar dapat mencapai tujuan organisasi yang ditetapkan; Mengelola pendidikan berarti aktivitas memadukan sumber-sumber pendi-dikan agar terpusat dalam usaha men-capai tujuan pendidikan. Ini artinya, substansi manajemen pendidikan adalah cooperation antara anggota organisasi untuk mencapai tujuan sesuai dengan fungsi manajemen. Karenanya, suatu manajemen dikatakan berhasil, jika keempat fungsi itu berjalan dengan baik. Kelemahan pada salah satu dari keempat fungsi manajemen, akan berpengaruh terhadap fungsi manajemen secara keseluruhan dan mengakibatkan tidak tercapainya proses yang efektif dan efisien. Dengan demikian, seorang manajer harus membekali diri dengan kemampuan kon-septual (antara lain POAC), kemampuan sosial dan kemampuan teknis yang dapat mendukung dalam pelaksanaan program yang dijalankan. Di bawah ini dijabarkan mengenai fungsi-fungsi manajemen yang dilaksanakan oleh ketiga Kepala RA di Kabupaten Cirebon.

Planning atau perencanaan adalah kemampuan untuk merencanakan suatu 
tindakan yang tepat dan akurat. Ketiga pengelola pendidikan RA yang dijadikan penelitian, setiap awal tahun selalu merancang program kerja dalam bentuk kalender akademik yang dijadikan pedoman program kerja selama setahun. Berdasarkan kalender akademik itu meliputi program kerja tahunan, program kerja tri wulan, program kerja bulanan, program kerja mingguan dan program kerja harian. Program kerja itu ada yang bersifat baku/ rutin, ada juga program kerja yang disesui-kan dengan kemampuan dan kemauan RA masingmasing. Kalender akademik yang dilaksanakan secara rutin ini harus dilaksanakan oleh pengelola RA dan harus didukung oleh orangtua/wali murid, sedang-kan kegiatan yang disesuaikan dengan kemampuan dan kemauan RA dan orang tua/wali murid, adalah kegiatan yang bersifat insidental dan tidak permanen. Dalam pelaksanaannya, hanya RA Wadi Fathimah dan RA Al-Washliyah yang secara konsisten dapat melaksanakan program kerja yang telah disusunya itu karena semua program kerjanya disetujui dan memperoleh dukungan masyarakat.

Organizing atau pengorganisasian berhubungan dengan pembagian tugas apa yang harus dikerjakan, siapa yang harus mengerjakannya, bagaimana tugas itu dikelompokan, siapa yang bertanggung jawab. Organizing terjadi karena pekerjaan yang perlu dilaksanakan itu terlalu berat untuk ditangani oleh satu orang saja.Ketiga Kepala RA yang dijadikan obyek penelitian, Kepala RA alWashliyah dan Kepala RA Thalaal Badru yang telah memahami dan menjalankan tugasnya, sehingga program akademik dan administratif berjalan dengan baik.

Actuating atau menggerakan, berhubungan dengan cara SDM menjalankan TUPOKSI yang ditentuan manajer melalui organizing. Ketiga Kepala RA yang dijadi-kan penelitian, telah memahami dan mela-kukan tugasnya dengan baik yaitu member motivasi dan pengarahan agarpara guru dan para stafnya menjalankan kewajiban sesuai Tupoksinya.

Controling atau pengawasan merupa-kan proses pemantauan yang secara terus menerus dilakukan oleh manajer terhadap mitra kerjanya untuk menjamin terlak-sananya Tupoksi. Ketiga Kepala RA yang dijadikan penelitian, telah memahami dan melakukan Tugas dan kewajibannya yaitu memberikan pengawasan dan penilaian terhadap kinerja para ustadz, ataupun pengelola RA lainya.

\section{Analisis}

Penilaian terhadap temuan-temuan hasil penelitian, penulis menggunakan kata telah sesuai (S), kuang sesuai (KS) dan belum sesuai (BS) dengan PP RI nomor 19 tahun 2005 tentang Sistem Nasional Pendidikan (SNP)terhadap komponen-komponen pendidikan RA di Kabupaten Cirebon. Komponenkomponen utama yang diniai meliputi 1) sarana dan prasarana, 2) pendidik dan tenaga kependidikan, 3) pengelolaan, 4) pembiayaan, dan 5) kurikulum, 6) program pembelajaran, 7) pembiayaan pendidikan.

Keadaan Sarana Fasilitas. PP RI nomor 19 tahun 2005 tentang Sistem Nasional Pendidikan (SNP) menyebutkan, satndard sarana dan prasarana yang harus ada pada setiap lembaga pendidikan formal adalah, minimal ruang belajar, ruang pimpinan, ruang pendidik, ruang tata usaha, tempat berolahraga, perpustakaan, tempat bermain. Kesemua sarana dan prasarana seperti ruang belajar, ruang pimpinan, ruang pendidik, ruang tata usaha, ruang perpus-takaan dan tempat bermain merupakan sebagian saja dari standard sarana dan prasarana yang harus ada dan diadakan oleh semua pengelola lembaga pendidikan. Karena kesemua sarana dan prasarana itu merupakan bagian dari sistem pengelolaan bagi suatu 
lembaga pendidikan formal, yang digunakan secara langsung sebagai pendu-kung dan penunjang keberlangsungan proses pendidikan dan pembelajaran. Kesemua sarana dan pra sarana tersebut memiliki fungsi yang amat mentukan bagi keamanan dan kenyamanan belajar dan membelajarkan anak-anak.

Ruang belajar atau tempat bermain, kedua prasarana ini harus ada karena keduanya berfungsi utama dalam proses pembelajaran dan interaksi antara guru dengan murid. Begitu juga dengan ruang pimpinan, ruang guru/ustadz dan ruang tata usaha. Jika ketiga prasarana tersebut tidak ada, maka dapat dimungkinkan fungsi pelayanan pimpinan dan tata usaha tidak akan berjalan dengan baik karena tidak adanya tempat dan sarana khusus yang harus dilakukan. Gambaran tersebut menunjukkan bahwa, sarana dan prasarana yang layak dan baik (laik) dengan dilengkapi peralatan dan tata ruang yang sesuai perkembangan usia anak belajar, sangat berpengaruh terhadap keberhasilan strategi pembelajaran yang sedang berlangsung; sarana dan prasarana yang laik, juga dapat berpengaruh terhadap pengembangan bakat minat dan motivasi anak untuk belajar.

Berdasarkan hasil pengamatan terhadap ketiga pendidikan RA yang dijadikan obyek penelitian, penulis menemukan bahwa pengelolaan pendidikan RA di Kabupaten Cirebon menunjukkan sebagian besar telah sesuai.

Peserta Didik (Murid). Peraturan Menteri Agama (PMA) No 90 Tahun 2013 tentang Penyelenggaraan Pendidikan Mad-rasah menyebutkan bahwa, "Raudhatul Athfal adalah salah satu bentuk satuan pendidikan anak usia dini pada jalur pendi-dikan formal yang menyelenggarakan pro-gram pendidikan dengan kekhasan agama Islam bagi anak berusia 4 tahun sampai 6 (enam) tahun".
Peraturan Pemerintah RI No. 17 tahun 2010 tentang Pengelolaan dan Penye-lenggaraan Pendidikan melalui Pasal 62 menyebutkan, pendidikan anak melalui jalur pendidikan formal berbentuk TK, RA atau bentuk lain yang sederajat. Pasal berikutnya (pasal 63) menyebutkan, murid atau anak yang belajar di TK/RA diatur melalui pasal berikutnya yang menyatakan bahwa, peserta didik TK, RA, atau bentuk lain yang sederajat, anak yang berusia 4 - 6 tahun.

Berdasarkan hasil pengamatan terha-dap ketiga pendidikan RA yang dijadikan obyek penelitian, diperoleh temuan bahwa, usia peserta didik yang belajar di pendidikan RA di Kabupaten Cirebon semuanya telah sesuai dengan UUSPN tahun 2003.

\section{Pendidik dan Tenaga Kependi-} dikan. PP RI No.19 Tahun 2005 tentang SistemNasionalPendidikan (SNP) terutama pada pasal 29, 30 dan 38 yang masing-masing menyebutkan, Pendidik pada pendi-dikan anak usia dini memiliki: a) kualifikasi akademik minimum diploma empat (D-IV) atau sarjana (S1), b) latar belakang pendi-dikan tinggi di bidang pendidikan anak usia dini, kependidikan lain, atau psikologi; c) serfikat profesi guru untuk PAUD (Pasal 29). Pada pasal 30 disebutkan bahwa, Pendidik pada TK/RA sekurangkurangnya terdiri atas guru kelas yang penugasannya ditetapkan oleh masingmasing satuan pendidikan sesuai dengan keperluan. Sedangkan pada pasal 38 disebutkan bahwa, kriteria untuk menjadi kepala TK/RA meliputi: a) Memiliki kualifikasi akademik dan kompetensi sebagai agen pembelajaran sesuai ketentuan perundang-undangan yang berlaku; b) Memiliki pengalaman mengajar sekurang-kurangnya 3 (tiga) tahun di TK/RA; c) Memiliki kemampuan kepemim-pinan dan kewira usahaan di bidang pendidikan.

Berdasarkan hasil pengamatan terhadap ketiga pendidikan RA yang 
dijadikan obyek penelitian, penulis menemukan di tiga pendidikan RA menunjukan, pendidik dan tenaga kependidikan pada penddikan RA di Kabupaten Cirebon kurang sesuai dengan PP 19 tahun 2005 tentang Sistem Nasional Pendidikan (SNP), sehingga masih perlu peningkatan terutama dalam hal kompetensi guru.

Kurikulum Pendidikan RA. Kurikulum merupakan seperangkat rencana dan pengaturan mengenai tujuan, isi, dan bahan pelajaran serta cara yang digunakan sebagai pedoman penyelenggaraan kegiatan pembe-lajaran untuk mencapai tujuan pendidikan tertentu. Kurikulum adalah sebuah pedoman dalam sebuah satuan pendidikan, sehingga penyampaian pembelajaran sebaiknya sesuai dengan kurikulum yang telah ditetapkan. Kurikulum pendidikan RA mengembangkan kurikulum terpadu atau kurikulum bersifat menyeluruh (Holistic). Penggunaan kurikulum ini mempunyai tujuan memberi kesempatan untuk mengembangkan semua asfek pekembangan, asfek perkembangan intelektual, dorongan hubungan social, perkembangan emosi dan fisik anak.

Berdasarkan hasil observasi dan wawancara dengan pengelola di tiga pendidikan RA Kabupaten Cirebon yang dijadikan obyek penelitian ditemukan, penggunaan kurikulum di RA secara umum telah sesuai dengan tujuan pendidikan keaga-maan.

Program Pembelajaran. Program Pembelajaran yang dilaksanakan oleh pengelola pendidikan RA di Kab. Cirebon yang dijadikan sebagai obyek penelitian, berdasarkan hasil pengamatan terhadap ketiga pendidikan RA yang dijadikan obyek penelitian ketiganya dapat dikategorikan cukup, sehingga masih perlu peningkatan dalam penyusunan program pembelajaran agar menjadi lebih baik. Program pembe-lajaran yang berpedoman kepada kurikulum harus lebih dapat diaktualisasikan di dalam proses pembelajaran sehingga dapat memberikan perubahan tingkah laku peserta didik kepada pengembangan potensi peserta didik. Pelaksanaan kegiatan belajar pada pendidikan RA di Kabupaten Cirebon me-nunjukan telah baik dan telah sesuai dengan PP Nomor 19 tahun 2005 tentang Sistem Nasional Pendidikan (SNP). Pelaksanan pembelajaran yang dilaksanakan oleh guru sangat diterima oleh masyarakat sekitar, terlihat dari dukungan masyarakat yang mendaftarkan putra/putrinya ke RA yang berada di sekitar rumah. Hanya saja dalam pelaksanaan pembelajaran ini masih perlu lebih ditingkatkan kembali sehingga mencapai hasil yang lebih baik di masa datang.

Berdasarkan hasil pengamatan terhadap ketiga pendidikan RA yang dijadikan obyek penelitian di Kabupaten Cirebon masih ada yang perlu diperbaiki dan ditingkatkan.

Pembiayaan Pendidikan. Pengelola pendidikan RA di Kabupaten Cirebon, dalam mengelola biaya pendidikannya ber-dasarkan hasil pengamatan terhadap kertiga pengelola pendidikan RA yang dijadikan tempat obyek penelitian diperokeh gam-baran, lebih banyak memperoleh bantuan dan dukungan dananya dari masya-rakat melalui pembayaran "bulanan" (syahriah) atau SPP dan lainnya, terutama dari orang tua/wali yang memasukkan anaknya ke RA pilihannya. Kecuali itu, ada bantuan dari Pemerintah Kabupaten Cirebon dalam bentuk operasional dan tunjangan fungsional (TF) secara berkala kepada guru RA yang telah memiliki Nomor Urut Tenaga Kepen-didikan (NUPTK).

Karena itu berdasarkan kenyataan tersebut, pembiayaan yang diperoleh dan dikelola oleh pendidikan RA di Kabupaten Cirebon yang dijadikan sebagai subyek penelitian bahwa semua pengeloa pendi-dikan RA dalam mengelola biaya pen-didikannya dapat dikageorikan telah sesuai dengan PP 
nomor 19 tahun 2005 tentang SistemNasionalPendidikan (SNP)

\section{Kesimpulan}

Para pengelola pendidikan RA di Kabupaten Cirebon telah melak-sanakan perencanaan baik perencanaan pendidikan maupun perencanaan pembelajaran. Peren-canaan pendidikan, dilakukannya sejak awal perintisan hingga perkembangan RA di tengah-tengah masyarakat dan telah menye-suaikan diri dengan PP RI No 19 tahun 2005 tentang Sistem Nasional Pendidikan (SNP).

Perencanakan (planning) program kerja lembaga, para pengelola pendidikan RA di Kabupaten Cirebon sejak awal tahun pelajaran telah menyusun kalender aka-demik yang dipersiapkan untuk dilaksana-kan selama satu tahun. Karena itu, kalender akademik dijadikan panduan dalam menjalankan program kerja. Sedangkan perencanaan pembelajaran, semua pengelola RA telah melakukan penyusunan materi ajar dalam bentuk satuan kegiatan mingguan (SKM), satuan kegiatan harianan (SKH), buku ajar, alat dan media belajar. Dalam penyusunan SKM dan SKH para ustadz mengacu pada Kurikulum RA meliputi 10 bidang pengembangan. Kenyataan ini karena adanya keterlibatan Pengurus IGRA Kabupaten Cirebon yang secara periodik mengadakan pelatihan akademik dan administratif kepada para Kepala RA dan para guru/ustadz RA.

$$
\text { Dalam hal organisasi }
$$

(Organization), Kepala RA di Kabupaten Cirebon telah menjalankan fungsinya sebagai manajer pendidikan yaitu menentukan pelaksana pendidikan sesuai kompetensisnya, sehingga program kerja administratif dan akademik dapat dilaksanakan sesuai tujuan organisasi pendidikan RA. Ada tiga Kepala RA yang sistem organisasinya sudah rapih dan sesuai dengan PP RI no. 19 tahun 2005 tentang Sistem Nasional Pendidikan (SNP) itu adalah RA al-Washliyah
Sumber, RA Thala'al Badru Gunung Jati dan RA Wadi Fathimah Kedawung.

Berkaitan dengan penggerakan (actua-ting), Kepala RA di Kabupaten Cirebon telah menjalankan fungsinya sebagai mana-jer pendidikan yaitu selau memberikan pengarahan dan memotivasi kepada para pelaksana pendidikan agar melayani segala kebutuhan murid dengan sebaik mungkin. Para Kepala RA tampaknya telah baik dalam memperlakukan bawahannya, dan sesuai dengan PP RI no. 19 tahun 2005 tentang SNP berkaitan dengan pengelolaan. Terdapat tiga Kepala RA yang telah melaksanakan prinsip dan dasar manajemen dengan baik yaitu Kepala RA al-Washliyah Sumber, Kepala RA Wadi Fathimah Kedawung, Kepala RA Thala'al Badru GunungJati.

Terkait dengan pengendalian (controlling), semua Kepala RA di Kabupaten Cirebon telah memahami dan melakukan tugasnya sebagai manajer yaitu mengen-dalikan organisasi pendidikannya dengan baik. Mereka kerap kali memberikan penga-wasan dan penilaian terhadap kinerja para pelaksana pendidikan lain dengan baik. Ketiga Kepala RA yang tampaknya telah baik dalam melakukan pengawasan dan menilai bawahannya yaitu Kepala RA alWashliyah Sumber, RA Wadi Fathimah Kedawung, RA Thala'al Badru GunungJati.

\section{Daftar Pustaka}

al-Halwani, Aba Firdaus dan Harini, Sri, Mendidik Anak Sejak Dini. Kreasi Wacana, Yogyakarta: 2003.

Alwaliah, Chaidir, A, Pokoknya Kualitatif, Bandung: 2007

Arikunto, Suharsimi, Yuliana, Lia, Manajemen Pendidikan, Yogyakarta: Aditya Media, 2008. 
Hasibuan, Malayu S.P., Manajemen Dasar Pengeritan dan Masalah, Bumi Aksara, Jakarta, Cet. Ke-9 2011

Maulana Haji, Fajar. Mendidik Anak Sejak Dini Menuju Anak yang Kreatif. Penerbit Jawara, Surabaya: 2000.

Permendiknas RI Nomor 16 Tahun 2007 tentang Standar Kualifikasi Akademik dan Kompetensi Guru

Permendiknas RI No 20 Tahun 2007 tentang Standar Penilaian Pendidikan.

Peraturan Pemerintah Nomor 17 Tahun 2010 tentang Pengelolaan dan Penyelenggaraan Pendidikan

PP RI nomor 55 tahun 2007 tentang Pendidikan Agama dan Keagamaan

Qomar, Mujamil, Manajemen Pendidikan Islam: Strategi Baru Pengelolaan Lembaga Pendidikan Islam, Erlangga, Jakarta: 2008.
Sukarji dan Umiarso, Manajemen dalam Pendidikan Islam, Mitra Wacana Medai, Jakarta: 2014

Terry, R, George, Guide to Management (Prinsip-prinsip Manajemen) Terj, J. Smith D.F.M, , Bumi Aksara, Jakarta: Cetakan ke-11, 2014

Trianto, Desain Pengembangan Pembelajaran Tematik bagi Anak usia Dini, TK/RA dan Anak Usia kelas awal SD/MI, Kencana Predina Prenada Media Group, Jakarta, 2011

Usman, Husaini, Manajemen Teori, Praktik, dan Riset Pendidikan, Bumi Aksara. Jakarta: 2006.

Undang Undang RI nomor 20 tahun 2003 tentang Sistem Pendidikan Naional, Jakarta: 2003 